\title{
Effect of Extract of Ailanthus Excelsa on Red Cotton Bug (Dysdercus Cingulatus)
}

\author{
Harshalata Sontakke, Irshad Baba, S.M. Jain, R.C. Saxena and Mahesh Ningwal \\ Pest Control \& Ayurvedic Drug Research Lab. S.S.L. Jain College, Vidisha.
}

\begin{abstract}
Botanical pesticides have pesticidal or ovicidal or repellent activities. The development of resistance to existing conventional synthetic pesticides and the increasing public concern over environmental pollution and health hazards created by synthetic pesticides, generate a great need for new types of pest management agent's advantage with higher activity against the target pests, and lower impact on humans and environmental quality. Repellents are the chemicals which cause an insect to make an oriented movement away from its source. Due to their odoriferous nature, oils of plants have been used for this purpose. Repellency in the present study has been noted visually in the treated insects and the observations recorded have been depicted. The results showed $95 \%$ repellency in the treated arms of petridish in fraction of Ailanthus ecxcelsa.
\end{abstract}

Key Words: Pesticides, repellent, odoriferous and Ailanthus ecxcelsa.

\section{Introduction:}

Cotton has the greatest insect predation problem. In India, to protect the cotton crop from insect attack, huge amount of pesticides are applied to the cotton fields in recent years as a consequence of extensive use of synthetic pesticides have emerged lot of problem such as pest resistance to the insecticides as well as human health hazards. In India, cotton production is about 295 million bales $(\approx 480 \mathrm{lb}$ bales $)$ during 2009-2010 against 113.9 million bales in the rest of the world. India also has the largest area under cotton cultivation (10.31 million ha), and yield was $486 \mathrm{~kg}$ ha-1 during 2009-2010 (Cotcorp, 2011).

The red cotton bug, Dysdercus cingulatus F. is an important pest of cotton and okra. Although synthetic chemical insecticides can control it, the side effects are enormous. In view of this, less hazardous options such as use of resistant cultivars, behaviour modifiers and insect growth regulators have gained prominence in agricultural pest management protocols. Several plant based compounds, which are potent sources of insect growth regulators and sterilants have been evaluated in this respect (Prabhu et al., 1973; Saradamma, 1989). Application of these phytochemical cause multiple growth and reproductive aberrations in insects (Jaiswal and Srivastava, 1992). Unlike modern pesticides, they also have the potential to reduce population of insects in the succeeding generations; thus forming an ideal component of the ecological pest management systems.

The present study was therefore undertaken with the following aims and objectives:

To observe growth inhibitory activity in Dysdercus cingulatus commonly known as red cotton bug.

\section{Materials And Methods:}

The plant material i.e. Bark of Ailanthus excels was collected from the field around Pandhurna. The plants was identified and authenticated by the taxonomist of botany department of S.S.L. Jain College Vidisha. A voucher specimen of the plant material was procured in the herbarium data sheet of the laboratory. The plant material was washed thoroughly with water and then air dried in shade at room temperature $25 \pm 2^{\circ} \mathrm{c}$ for more than 15 days. The air dried plant material was grinded to powder about $40-$ 60 mesh size. The $50 \mathrm{gm}$ of the powdered material was loaded into soxhlet apparatus separately for extraction with the solvent of increasing order of polarity (n-Hexane, Chloroform and Methanol). The extract was filtered through Whatman's filter paper. Then the crude extract was concentrated in the vacuum rotary evaporator. The crude extract obtained from plants was tested for various biological activities against Dysdercus cingulatus.

\section{Insecticidal And Ovicidal Effect Of Biocides On Red Cotton Bugs, Dysdercus Cingulatus:}

Dysdercus cingulatus were collected and cultured in the laboratory at optimum temperature (27 \pm $2^{\circ} \mathrm{c}$ ) and $\mathrm{RH}$ about $80 \%$. Freshly laid eggs (50) were treated 5 times with $100 \mathrm{ppm}$ of the extract $(0.5 \mu \mathrm{l})$. The control eggs (50) were treated with equal amount of acetone. The sterility index (S.I.) was calculated using the following formula:

$$
\mathrm{SI}=100-\left(\frac{\text { test no.of eggs } \times \% \text { eggs hatch }}{\text { control no.of eggs } \times \% \text { eggs hatch }}\right) \times 100
$$




\section{Observation And Results:}

Ovicidal activity was observed by treating the eggs with $0.5 \mu \mathrm{l}$ doses of 3 different concentrations of the extract. For this freshly laid eggs $(0-24 \mathrm{hrs}) 100$ in number were taken for each treatment. Observations were made up to $7^{\text {th }}$ day after treatment for egg mortality and hatching percentage.

\section{Ovicidal activity of extracts of Ailanthus excelsa on Dysdercus cingulatus}

\begin{tabular}{|l|l|l|l|l|l|}
\hline Conc. & $\begin{array}{l}\text { No. of treated } \\
\text { eggs }\end{array}$ & $\begin{array}{l}\text { Average no. o } \\
\text { fdead eggs }\end{array}$ & $\begin{array}{l}\text { Egg mortality } \\
(\mathbf{\%})\end{array}$ & $\begin{array}{l}\text { Corrected adult } \\
\text { emergency }\end{array}$ & $\begin{array}{l}\text { Sterility index } \\
\text { (SI) }\end{array}$ \\
\hline 1. & 100 & 56.66 & 56.66 & 42 & 19.2 \\
\hline 2 & 100 & 75.33 & 75.33 & 24 & 25.53 \\
\hline 3 & 100 & 81.33 & 81.33 & 16.2 & 44.68 \\
\hline Control & 100 & 4.66 & 4.66 & 94 & \\
\hline
\end{tabular}

Due to their odoriferous nature, oils of plants have been used for this purpose. Repellency in the present study has been noted visually in the treated insects and the observations recorded have been depicted in table given below. The results in the table showed $95 \%$ repellency in the treated arms of petridish in fraction of Ailanthus ecxcelsa.

Showing repellent activity of crude and purified fraction of Ailanthus excelsa on Dysdercus cingulatus

\begin{tabular}{|l|l|l|l|}
\hline \multirow{2}{*}{ Concentration ppm } & \% average number of insects repelled & Purified fraction \\
\cline { 2 - 4 } & Chloroform crude extract & Methanol crude extract & 70 \\
\hline 100 & 55 & 60 & 75 \\
\hline 200 & 62 & 64 & 82 \\
\hline 300 & 70 & 64 & 87 \\
\hline 400 & 73 & 75 & 0 \\
\hline Untreated & 0 & 0 & \\
\hline
\end{tabular}

25 adult insects were released in each petridish marked with treated and untreated at equal half of whatman's filter paper, $0.5 \mu \mathrm{l}$ of each concentration was sprayed on the filter paper on treated arm.

$0-24$ hrs eggs were used for ovicidal activity

It has been noticed that the insects in treated arm as soon as come in contact with the filter paper containing higher concentration of the compound tend to rush immediately to the opposite direction of the untreated arm of petridish. The repellency seems to be quite dose dependent, highest the concentration maximum is the activity. Among the three extracts, it was noticed that both chloroform and methanol crude extracts possess similar activity to the insect Dysdercus cingulatus. The repellent activity persists only for few hours, and then it declines gradually.

\section{References:}

[1]. Cotcorp. (2010). The Cotton Corporation of India Ltd., Navi Mumbai, India. Available at http://cotcorp.gov.in (accessed March 2011).

[2]. Cox, M. L. (1993). Red palm weevil, Rhyncvhophorus ferrugineus in Egypt. FAO Plant Protection Bulletin, 41(1): 30-31.

[3]. Dave Kain. (2000). Update on Pest Management and Crop Development. Scaffolds fruit Journal, V. 9, No. 20.

[4]. Don Pedro, K.N. (1985). Toxicity of some pests to Dermestes maculates Sig. and Callosobruchus maculates Fabr. J. Stored Prod. Res. 21(1):31-34.

[5]. Jaiswal, A.K. and Srivastava, U.S. (1992). Mating disruption in Dysdercus cingulatus caused by Blumea laciniata extracts. J. Appl. Zool. Res., 3: 151-153.

[6]. Prabhu, V.K.K., John, M. and Ambika, B. (1973). Juvenile hormone activity in some South Indian plants. Curr. Sci., 42: $725-726$

[7]. Saradamma, K. (1989). Biological activity of different plant extracts with particular reference to their insecticidal, hormonal and antifeeding actions. PhD Thesis, Kerala Agricultural University, Thrissur, 252p.

[8]. Schmutterer. H. and Singh. R. P.(1995). List of insect pests susceptible to neem products. In The Neem Tree Source of Unique Natural Products for Integrated

[9]. Schoonhoven, L. M. (1981). Chemical mediators between plants and phytopagous insects. In, Semiochemicals, Their Role in Pest Control, ed. by D. A. Nordlund, K. L. Jones, and W. J. Lewis, pp. 31+50, Wiley, New York.

[10]. Su, H.C.F. and Horvat, R. (1988). Investigation of main component in insect-active dill seed extract. J. Agric. Food Chem. 36(4):752753.

[11]. Sahayaraj, K. and Illayaraja, R. (2008). Ecology of Dysdercus cingulatus (Fab.morphs. Egyptian Journal of Biology, 10, $122-125$.

[12]. Sahayaraj, K. and Shoba, J. (2012). Toxic Effect of Tephrosia purpurea (Linn.) and Acalypha indica (Linn.) Aqueous Extracts Impact on the Mortality, Macromolecules, Intestinal Electrolytes and Detoxication Enzymes of Dysdercus cingulatus (Fab.). Asian Journal of Biochemistry. 7(3): 112-122.

[13]. Rizwan-Ul-Haq, M. ,Sabri M A, Rashid, A. (2005). Toxicity of Nicotinyl insecticides on the haemocytes of Red Cotton Bug Dysdercus koenigii (Fb) (Pyrrhocoridae : Hemiptera ) Journal of Agriculture and Social Sciences , 1 (3) 239-241.

[14]. Renuga, F.B., and K. Sahayaraj. (2009). Influence of botanicals in total head protein of Spodoptera litura (Fab.) Journal of Biopesticides 2:52-55

[15]. Nassar, M.M.I. and Abdullah, M.A. (2001). Evaluation of Azadirachtin for the control of the red palm weevil Rhynchophorus ferrugineus (Oliv.) (Coleoptera- Curculionidae). J. Egypt, Ger. Soc. Zool.V(36) 163-173pp.

[16]. Manilal, A., S. Sujith, G. Seghal Kiran, J. Selvin, C. Shakir, R. Gandhimathi, and M.V. Natraja Panikkar. (2009). Biopotentials of seaweeds collected from southwest coast of India. Journal of Marine Science and Technology 17:67-73. 